\title{
Grupo de apoio aberto para pessoas portadoras do HIV: a construção da homogeneidade
}

\author{
Emerson F. Rasera \\ Marisa Japur \\ Universidade de São Paulo - Ribeirão Preto
}

\begin{abstract}
Resumo
Há um debate na literatura a respeito da homogeneidade na composição dos grupos para portadores do HIV, segundo estágios da doença, formas de infecção e sexo dos participantes. Este estudo, baseado em uma concepção construcionista da terapia e da produção do conhecimento, buscou analisar como os sentidos sobre a soropositividade e o apoio eram negociados em uma sessão de um grupo de apoio voltado a esta população. Observamos que a homogeneidade e o apoio, antes de serem categorias a priori usadas para organizar o grupo, são ativamente construídas na e através da situação grupal por seus participantes. Implicações éticas e metodológicas decorrentes dessa análise apontam para o reconhecimento das condições sócio-históricas de construção dos sentidos da soropositividade e da hegemonia de algumas de suas descrições.
\end{abstract}

Palavras-chave: psicoterapia de grupo, composição grupal, AIDS, construcionismo social

\begin{abstract}
Open support groups for persons living with HIV/AIDS: the construction of its homogeneity. There is a debate in the literature regarding the homogeneity in the composition of the groups for persons with HIV/AIDS, according to stages of the disease, infection forms, and the participants' sex. This study, based on a constructionist conception of the therapy and of the production of the knowledge, sought analyzing how the senses on the seropositivity and the support were negotiated in a session of a support group oriented to this population. We observed that the homogeneity and the support, before being a priori categories used to organize the group, are actively built in and through the group setting by its participants. Ethical and methodological implications of this analysis point to the recognition of the social-historical conditions for the construction of the senses of the seropositivity and of the hegemony of some of its descriptions.

Keywords: group psychotherapy, group composition, AIDS, social constructionism
\end{abstract}

$\mathrm{D}$ esde o seu surgimento, a AIDS vem impondo diversos desafios a toda a sociedade. A contribuição da Psicologia nesse campo tem sido dada de diversas maneiras, seja no aconselhamento pré/pós testes, em psicoterapia individual a pacientes ambulatoriais e internados, em psicoterapia de grupo com pacientes soropositivos e seus familiares, bem como com os profissionais que lidam com pessoas com HIV/AIDS (Catalan, 1995; Kelly, 1998; Lego, 1996).

Na literatura sobre atendimento em grupo a pessoas portadoras do HIV, as experiências relatadas são diversificadas: as modalidades utilizadas têm abrangido grupos de apoio atendendo a pacientes em tratamento ambulatorial (Spector \& Conklin, 1987), grupos abertos (Grant, 1988), grupos psicoeducativos de orientação cognitiva comportamental (Levine, Bystritsky, Baron \& Jones, 1991), grupos fechados
(Kelly et al., 1993) e também grupos de ajuda-mútua (Bonet, Ferrer \& Vilajoana, 1994).

A eficácia destes tratamentos grupais tem sido apontada por alguns autores (Kelly et al., 1993; Levine et al., 1991). O grupo possibilita ao participante uma fonte substituta de apoio e encorajamento, faz diminuir seus medos, ansiedades, a sensação de isolamento e proporciona a aprendizagem de novas maneiras de lidar com o HIV/AIDS (Bonet et al., 1994; Grant, 1988; Lego, 1996). As intervenções grupais capacitam seus membros a desenvolver um senso mais positivo de si próprio, serem mais ativos e seguros, havendo aumento de autoestima e o encontro de novos significados na vida (Getzel, 1991).

Na literatura sobre intervenções grupais com portadores do HIV encontram-se também vários artigos que descrevem experiências de tratamento de pessoas com HIV/AIDS 
alertando para as especificidades do manejo clínico no atendimento do paciente soropositivo (Bernstein \& Klein, 1995; Tunnell, 1991) e apontando que ainda constitui um desafio aos profissionais da saúde mental o acompanhamento psicológico ao portador do HIV.

Neste sentido, há um debate na literatura a respeito da composição dos grupos para portadores do HIV. Há autores, como Spector e Conklin (1987), que sugeriram que os grupos devem ser compostos por pacientes em estágios similares da doença. Outros, como Barros (1997), relataram experiências grupais produtivas em que participaram pacientes em diferentes estágios da doença. Além disso, a homogeneidade na composição do grupo, segundo formas de contágio, parece segundo alguns autores facilitar a coesão e o desenvolvimento do trabalho grupal (Gamble \& Getzel apud Lego, 1996; Tunnel, 1991). Através da análise de algumas pesquisas, Siebert e Dorfman (1995) investigaram como o estágio da doença, a forma de contágio e o gênero influenciavam na presença de três fatores terapêuticos, quais sejam, instilação de esperança, universalidade e coesão. Eles sugeriram que grupos de apoio homogêneos quanto a tais variáveis facilitavam a ação de tais fatores propiciando a seus participantes maiores benefícios. É importante observar que dentre todos o fatores terapêuticos que ocorrem em um grupo, os selecionados para este estudo estão entre aqueles, a priori, mais influenciados pela homogeneidade. Seria necessário analisar como esta composição infuenciaria a ação de outros fatores terapêuticos. Contudo, permanece o debate sobre a melhor forma de compor os grupos para pessoas portadoras do HIV.

Além disso, é importante ressaltar que estes estudos não trazem como questão o processo de desenvolvimento destas estratégias psicoterápicas. As pesquisas sobre grupo de apoio para pessoas portadoras do HIV, pensadas a partir de uma ótica que visa a generalização dos resultados, não possibilitam compreender como se dão processos mais sutis de construção das pessoas através do processo psicoterápico, os quais, em última análise, determinam o sucesso de uma intervenção.

\section{Objetivo}

O objetivo deste estudo é rastrear a construção dos sentidos produzidos em uma sessão de um grupo de apoio aberto para pessoas portadoras do HIV, especificamente no que se refere à construção da soropositividade e da possibilidade de apoio neste contexto, explicitando as múltiplas relações dialógicas que aí se produzem.

\section{Método}

Metodologicamente, este trabalho se orienta a partir de uma concepção sócio-construcionista da psicoterapia e da produção do conhecimento (Gergen,1994; Spink, 1999), a qual, através de uma crítica a uma concepção de conhecimento como representação, redimensiona a relação sujeito-objeto, a natureza do real, e promove uma visão da ciência enquanto produção sócio-histórica. Privilegia então o estudo da linguagem enquanto constituinte de práticas sociais produtoras da realidade, enfatizando a análise do processo de cons- trução dos sentidos. Baseada em uma visão narrativa do self, investiga os momentos interativos nos quais sentidos e pessoas se constróem, através de conceitos tais como o de dialogismo (Bakhtin, 1997) e posicionamento (Davies \& Harré, 1990). O dialogismo se refere à proposição de Bakhtin de que a relação com o outro é o fundamento da língua e da constituição do ser. Este princípio dialógico permeia toda produção discursiva e nega qualquer possibilidade de entendê-la como individual, seja porque ela se dá entre interlocutores sociais, seja porque mantém relações com outros discursos. Já o conceito de posicionamento se refere à produção discursiva do self, à construção das pessoas durante uma conversação. Para Davies e Harré (1990), “um indivíduo emerge através dos processos de interação social, não como um produto final relativamente fixo, mas como alguém que é constituído e reconstituído através das várias práticas discursivas nas quais participa” (p. 46). O posicionamento consiste de "uma possibilidade em formas conhecidas de conversar", e portanto tem um caráter mutante dependendo de como uma conversa se desenvolve, das narrativas, e metáforas das quais o processo de posicionamento está sendo constituído. No processo psicoterápico, ressalta-se este caráter discursivo e dialógico de produção do self. Através da abertura de espaços para conversação, a ênfase na terapia recai sobre a necessidade de vivência da multiplicidade, o que permite a relativização dos sentidos, a aceitação da indeterminação e a compreensão de que não há uma história pessoal única e definitiva.

\section{O objeto de estudo}

A intervenção estudada no presente trabalho é parte do Programa de Atendimento Psicossocial em AIDS da FFCLRP/ USP, no qual um dos autores deste artigo coordena o Grupo de Apoio. O grupo recebe portadores do HIV encaminhados pelos diversos serviços de saúde da cidade, e funciona como grupo aberto, sendo realizado semanalmente, com duração de 1h30. O terapeuta atua de forma a estimular conversações dialógicas, promovendo o acolhimento, o exercício da reflexividade e a construção de novas descrições das situações trazidas pelos participantes.

\section{A construção do corpus}

Os procedimentos de constituição do corpus consistiram de registro audio-gravado de 10 sessões grupais; aplicação de um questionário pós-sessão, através do qual se investigou os momentos marcantes na sessão para seus participantes, e constituição de um diário de campo. Realizou-se uma análise comparativa das dez sessões a partir das categorias de: composição, conteúdo, clima afetivo, padrão de interação, impressões do terapeuta e impressões dos participantes. Identificou-se então uma sessão que era semelhante a muitas outras em diversos aspectos, contudo, se diferenciava no tom afetivo presente na relação entre os participantes. Uma sessão com certo caráter disruptivo, que nos pareceu indicar algo não cristalizado, não estabilizado, a denunciar contradições que em outras sessões não apareciam ou eram encobertas por outras questões. Esta sessão, então, foi escolhida para uma análise extensiva, focada em cada enunciação do processo grupal. 
Análise da sessão: delimitações temáticosequenciais e definição dos eixos processual e temático

Escolhida a sessão, diversos passos foram tomados na análise da mesma: 1) leitura exaustiva da transcrição da sessão; 2) análise seqüencial de todo o material transcrito; 3) construção de eixos analíticos; 4) construção de delimitações temático-seqüenciais e 5) análise de posições e jogos de posicionamento (conforme descrito em Rasera \& Japur, 2001).

Assim, através destas diversas leituras, da discussão destas entre um grupo de pesquisadores, e da análise dos momentos recortados pelos participantes nos questionários, construímos os eixos analíticos temático e processual. O eixo temático focalizava os conteúdos das conversas grupais e o eixo processual colocava em destaque a ação promovida entre os participantes na conversa de cada um de tais conteúdos. A análise propiciada pelo eixo processual permitiu que os sentidos do contexto imediato se redimensionassem à medida que postos em diálogo com o contexto mais amplo da sessão.

À medida que esses eixos iam sendo construídos foi sendo possível também efetuar delimitações temático-seqüenciais na sessão. Estas delimitações permitiram explicitar a disputa pelos sentidos que determinada questão trazia. Havia em cada fala uma tentativa de determinação de um sentido e de domínio da interação por um dos participantes da sessão. Focalizávamos assim o caráter de negociação das trocas que ocorrem em uma sessão, explicitando as implicações identitárias das mesmas através dos jogos de posicionamento aí existentes. Buscando garantir o foco no processo grupal, a análise permeou todos os momentos do grupo em sua interdependência temporal, possibilitando uma compreensão do fenômeno grupal em sua instabilidade e complexidade.

Estas formas de análise do material nos permitiram focalizar o processo grupal e não apenas o indivíduo, reconhecendo-se o valor da fala de cada participante enquanto construtor da e construído pela situação grupal, inclusive o terapeuta.

\section{A sessão: negociando diferenças}

O contexto da sessão analisada foi o típico do serviço. Nesta sessão estiveram presentes quatro participantes: Maria, Ana, Marcos e Carlos, além do terapeuta.

Maria: participava pela 19a vez em uma sessão nesse serviço. 23 anos, separada do esposo, morava com os pais, nunca havia trabalhado fora de casa, tinha 20 grau completo. Era mãe de uma criança de 2 anos. Descobriu-se portadora há 8 anos, tendo se infectado por relação sexual com o seu antigo namorado. Queria encontrar outras pessoas com quem pudesse falar tudo o que pensava. Procurava amizades sinceras.

Ana: era a 2a vez que participava do grupo. 25 anos, separada do antigo companheiro, morava com os pais, tinha o 2o grau, não estava trabalhando, era secretária. Descobriuse portadora durante a gravidez, há 11 meses. Seu ex-compa- nheiro, pai de seu filho, não se infectou. Acreditava que se infectou por um antigo namorado. Procurou o grupo para não se sentir tão sozinha, ter apoio e ver que "sua vida pode ser normal”.

Carlos: era a 1a vez que participava. 38 anos, separado da esposa, estudou até o 20 grau, morava com os pais, estava desempregado, era operador de microcomputador. Descobriuse portador do HIV há 2 anos. Infectou-se provavelmente através do uso de drogas injetáveis. Fazia acompanhamento médico, e era o único participante que não tomava medicação. Procurou o serviço pois se sentia fragilizado, com medo e queria ajuda. Curiosamente afirmava que tinha medo de morrer, não pelo HIV, mas pela hepatite $\mathrm{C}$, que também possuía.

Marcos: já havia participado em 6 sessões do grupo, mas fazia dois meses que não comparecia às sessões. Estava em uma casa de apoio da qual não podia sair para vir ao grupo. Foi para lá pois teve dificuldades financeiras, problemas de saúde, não tinha com quem ficar durante todo o dia e precisava de cuidados. 44 anos, cursou o primário, era solteiro, cozinheiro, aposentado atualmente, devido as dificuldades com a saúde. Morava sozinho. Sabia-se portador há 3 anos. Infectou-se por relação homossexual. Já havia tido algumas doenças oportunistas. Dizia procurar outras pessoas para conversar, pois em casa ficava muito sozinho, acabava deprimindo-se e queria fazer novos amigos com o mesmo "problema” que ele.

Terapeuta: 26 anos, psicólogo, há três anos atendia pessoas portadoras do HIV. Era pós-graduando e estudava modelos de atendimento psicológico àqueles que vivem com HIV/AIDS.

A sessão será apresentada conforme os eixos de análise construídos. Assim, em um eixo denominado processual, analisaremos a sessão, em seus diversos momentos, enquanto uma "negociação da diferença" entre os participantes do grupo. Esta análise se objetiva concretamente através do estudo de dois eixos temáticos das conversas dos participantes: a construção do que é "ser soropositivo" e a possibilidade de “encontrar apoio”.

Concomitante à criação destes eixos, a sessão foi dividida em momentos, através de delimitações temáticoseqüenciais. Estes momentos são marcados por questões orientadoras que implicam um desenvolvimento temático específico. Estão apresentados a seguir segundo a ordem cronológica da sessão.

\section{Momento1: o estranho que chega}

O grupo se inicia com Maria, Ana e Carlos, que participava pela primeira vez. Realiza-se então o contrato grupal, que estabelece determinadas condições conversacionais entre os participantes. Neste momento, buscando se aproximar do grupo e do terapeuta, Carlos se apresenta como Carlos-que-sabetudo-de-tratamento-psicológico e Carlos-que-foi-expulso-deum-serviço-de-saúde-mental.

Conheço este tipo de trabalho. Eu já fui no A (hospital psiquiátrico da região) (...), então eu conheço tudo o trabalho dos psicólogos. 
Só me expulsaram de lá porque um rapaz (...) quis crescer pro meu lado. (...) Aí eu peguei e meti a mão nele lá dentro. Aí eles expulsaram eu de lá.

Esta forma de se apresentar de Carlos constitui um sinal de ameaça ao grupo, de possível violência e dificuldade de contato com o outro, que faz o terapeuta explicitar alguns aspectos do contrato sobre a forma de relacionar-se no grupo e os assuntos e necessidades mais comumente trabalhados, buscando reassegurar para os outros participantes suas condições de participação.

O quê que a gente conversa? Geralmente, sobre a vida das pessoas, né, e o que que ela tem, o que que a questão do HIV, da AIDS mudou na vida das pessoas né. Então aqui acaba sendo um lugar que essas pessoas conseguem falar um pouco, se aliviar e daí ficar com força pra levar a vida (...)

(...) pra conhecer um pouquinho as dificuldades que o Carlos tem enfrentado, né, umas dificuldades um pouco diferentes das outras pessoas que estão aqui viu Carlos, eu já lhe adianto um pouco isso, né.

Há um duplo sentido no contrato proposto pelo terapeuta, a partir da fala de Carlos e da reação dos outros participantes em relação a ele: aproximação das diferenças, facilitando a interação entre os participantes e afirmação de uma distinção entre Carlos e os outros do grupo.

\section{Momento 2: chegou mais um de nós}

Neste momento, há a volta de Marcos (7a sessão, após um período de afastamento do serviço) que por diversas dificuldades havia buscado uma Casa de Apoio. A chegada do familiar faz Maria participar mais espontaneamente sendo seguida de Ana. Ana-que-procura-outros faz perguntas para Marcos-que-ficou-deprimido em uma interação na qual há complementaridade de falas.

Marcos, deixa eu te fazer uma pergunta, quê que fez você procurar lá (a casa de apoio)?

(...) O que fez é porque eu tava muito sozinho, eu não tinha, eu não tava recebendo INPS, tava tudo atrasado (...) chegou até a cortar a luz (...)

Carlos-alcoólatra conta de sua experiência em Casa de Apoio e ressalta a importância de viver com a família. Anasem-apoio-do-marido-soronegativo e com vontade de ir para Casa de Apoio discorda. São falas que competem.

Sabe, eu tava falando pra Maria, porque quando eu me separei, eu pensava assim, 'Eu vou agora deixar o meu filho com a minha mãe, e vou procurar uma casa assim de apoio’. Eu acho que eu ia me sentir assim, mais útil e também ia conhecer e ter apoio das outras pessoas (...) eu acho que a pessoa pra entender a gente é só pessoa que tem, que passa a mesma coisa que a gente passa' (Ana)

Mas eu vou falar uma verdade pra vocês viu. Você ter um apoio de um pai, e de uma mãe, é preferível ficar em casa (Carlos)
Marcos explica a Ana que teve apoio de pessoas que não são portadoras do HIV.

Mas não é só a pessoa que tem que entende. Porque na casa de apoio as pessoas não tem, que tá lá, que trabalha lá. Eles entende, te dá o maior apoio (Marcos)

Através de Marcos constrói-se Ana-que-sabe-que-nãoé-só-quem-tem-HIV-que-pode-ajudá-la.

\section{Momento 3: a aproximação possível}

Este momento se inicia com uma pergunta de Carlos:

Agora, você desculpa, você pegou a doença através do quê, de drogas injetáveis?.

Maria logo lhe responde, em tom confrontativo:

Não, ninguém aqui ... ninguém pegou por droga aqui.

Carlos antecipa a infecção dos outros a partir da revelação de sua própria. Surge Carlos-que-se-infectou-pelo-usode-drogas-injetáveis e os outros-infectados-por-relaçõessexuais: diferenças que possuem diferentes valores que não podem ser discutidos.

A aproximação possível entre os participantes se dá na discussão sobre a liberação de medicamentos. Para falar das diferenças entre eles passam a discutir as diferenças no tratamento de cada um: Carlos-que-não-toma-medicação e os outros-que-tomam. Parece haver a construção do lugar marginal de Carlos na sessão: repetição do lugar fora do grupo?

Após a explicitação da diferença entre os membros do grupo relativa à forma de infecção, várias das tentativas de Carlos participar da conversa são abortadas pelos outros membros do grupo. A fala de Carlos não é complementada. As outras falas não respondem diretamente às colocações de Carlos. Parece que a marginalidade trazida por Carlos em sua história de vida, associada ao tráfico, ao uso de drogas, à loucura de sua vida é presentificada na relação dos participantes. Ele é, por vezes, posto à margem. É difícil reconhecer nele alguém como fonte de apoio, possível de identificação. Reproduz-se no grupo a discriminação social. Mulheres infectadas pelos parceiros são vítimas e devem ser cuidadas. Usuários de drogas injetáveis, responsáveis pela própria infecção, devem ser culpabilizados e postos à margem.

\section{Momento 4: afirmando a igualdade I - Ana e Marcos}

Ana redireciona ativamente os sentidos da sessão: quer conhecer Marcos. Carlos também quer falar e busca espaço apoiado pelo terapeuta. Ana se sente interrompida gerando uma tensão na sessão. Recuo de Carlos apoiado pelo terapeuta e não-confrontação. Marcos retoma e fala extensamente, a partir de perguntas de Ana, sobre sua soropositividade nas relações com empregadores, família, governo e aposentadoria.

Surge, durante a fala de Marcos, Carlos-que-não-consegue-se-aposentar. É um Carlos que, diferente de outros momentos, não gera tensão no grupo.

Mas é uma palhaçada. Eu fui, eu dei entrada, eles cancelaram (...). Aí em janeiro eu tinha que levar uma documentação, aí eles mandaram uma carta pra mim, eu fui lá e os caras pegaram 
e cancelaram o meu auxílio. Aí agora eu dei entrada de novo (...). É uma burocracia do inferno.

Ana não procura aposentadoria pois acredita que a cura virá. Fala que espera complementação.

Então, será que eles não tem assim porque, eu não vou atrás, assim, não que eu não vou atrás, eu acho que, eu tenho assim fé naquilo que eu sei que eu não vou precisar assim, que eu acredito na cura, que vai vir uma cura mesmo né (...).

A soropositividade parece implicar uma posição de dependência e um processo de vitimização.

\section{Momento 5: afirmando a igualdade II - Ana e Maria}

Em um diálogo privilegiado entre Ana e Maria surge Mariaque-desconta-o-sofrimento-no-marido (que volta após um período de separação) e Ana-sem-apoio-do-ex-marido. Dificuldade nas relações com os parceiros. Para Ana e Maria é no casamento que há a marca mais forte desta construção da soropositividade, que também aparece associada a uma posição de dependência e um processo de vitimização.

Mas ele (marido que voltou para ela) tá penando esses dias, coitado. Ele não tava acostumado com a minha filha né, então toda hora eu falo 'Vai olhar a Fernanda', 'Vai olhar a Fernanda'. Ele tá ficando descabelado. (...) Eu falei 'viu quanto é bom. Ser mãe sozinha não é fácil (...)’ (Maria)

Eu não tenho com quem... comigo tem que ser eu, eu ainda tenho que correr muito ainda, eu acho que eu vou correr o resto da minha vida atrás do meu (filho) sozinha. (Ana)

A participação no grupo faz surgir Ana-que-tem-apoio e Maria-que-não-tinha-só-o-marido.

(...) quando eu vivi com ele, eu não tinha amor próprio, e depois que eu comecei a vir aqui no grupo, conhecer outras pessoas, vi que não tinha só ele no mundo, que eu comecei a mudar. (Maria)

Eu falei pro meu ex-marido que eu depois que eu vim aqui na segunda-feira, eu falei pra ele 'Olha, eu me senti assim, como se fosse assim, nossa, como se eu tivesse, tava nascendo de novo, né que eu vi que num, que igual você fala que não é só eu que tenho, que não é ‘só eu que sofro’. (Ana)

O reconhecimento da experiência do outro legitima a própria experiência e permite que se "nasça de novo". As falas de Maria e Ana vão se complementando. Uma pareada à outra. A fala de Maria, mais experiente, guia a fala de Ana. Tal qual no momento quatro, neste momento cinco, falas complementares rumo à igualdade fazem a diferença se tornar opaca.

\section{Momento 6 - a diferença explicitada: guinada na sessão}

Frente aos comentários de Ana sobre a falta de apoio do ex-marido, e seu isolamento social, Carlos se posiciona quanto à revelação da soropositividade:
Eu vou ser sincero, eu, aonde eu moro ali, todo mundo sabe que eu tenho. Eu nunca menti pra ninguém, eu falei 'eu tenho, eu portei, eu procurei, e eu vou assumir'.

Esta fala de Carlos produz, através de um jogo de posicionamentos, um desconforto entre os outros participantes que são colocados por ele na posição de irresponsáveis.

Mas aí a gente tem criança pequena, os filhos da gente também
podem sofrer. (Maria, em tom confrontativo)
Isso... (Ana fala ao mesmo tempo)
Os meus filhos todos sabem que eu tenho a doença. (Carlos)

Mas os seus filhos são grandes, os da gente são pequenos e nasceram com o HIV. (Maria)

Eu sofro muito sabe, pelo meu filho, e eu sei que um dia ele, ele vai crescer né, eu tenho muita esperança nisso porque por enquanto ele tem. (Ana)

A voz da maternidade produz para Ana e Maria uma posição de culpada. Neste momento Ana e Maria ocupam a posição de vítimas (mulheres infectadas) e de culpadas (mães que transmitem) na situação de transmissão do HIV.

\section{Momento 7 - lidar com a diferença: trocando posições}

A revelação da soropositividade mostra mulheres que têm medo que seus filhos sofram. Carlos fica sensibilizado e tenta apoiar.

Olha, mas graças a Deus, você pode ficar sossegada porque vai vir essa cura, você pode esperar que daqui 2 anos vai vim essa cura.

Nova tensão na sessão. A fala de Carlos não pode ser vista como apaziguadora. Carlos não pode ser tão diferente do que vinha sendo antes. É a vez dele ser culpado. Centram a discussão na cura da AIDS. Carlos aceita o posicionamento decorrente da complementação dos outros que restringe determinados sentidos de sua fala, mantendo o foco na cura.

\section{Ah, eu não fico me iludindo. (Marcos) \\ Eu não acredito na cura. (Maria)}

Eu não acredito na cura. (Ana)

Neste momento sete, a diferença de Carlos em relação aos outros membros do grupo novamente aparece. Ele é o único que acredita na cura da AIDS. É importante observar que há um debate entre Carlos-que-acredita na cura e Anaque-não-acredita-na-cura. Esta no momento três acreditava na cura. Contudo, em cada um destes momentos acreditar na cura tem um sentido diferente. No momento quatro, acreditar na cura significava acreditar que se viverá muito, que há que se lutar, continuar a trabalhar, não se aposentar. Neste momento sete, acreditar na cura é se iludir, não olhar para a realidade. Diferentes contextos, posições e sentidos. 


\section{Momento 8: o estranho em nós}

Frente à tensão gerada pela discussão em torno da questão da cura da AIDS, o terapeuta tenta aproximar os participantes. Investiga entre os participantes como é viver sabendo que essa doença não tem cura.

Surge Carlos-com-pouco-tempo-de-vida. No processo desta sessão completa-se a construção da vitimização de Carlos.

(...) eu tenho pouco tempo de vida, eu não sei quanto. Quer dizer, então agora, tá na mão de Deus e eu tô esperando, tô vivendo o meu dia-a-dia, quando eu acordo eu dou um grande sorriso e agradeço a Deus por ter me acordado e é só isso.

Ao mesmo tempo, surgem as mães-culpadas, retomando-se alguns sentidos dos momentos 5 e 6 , bem como Marcos-culpado:

\section{A maior pessoa culpada é eu. (Marcos)}

(...) eu olhava pra ele [o filho] , eu falava 'Gente, mas Deus tá me castigando tanto, tanto, será que eu tô merecendo tudo isso? Descobri na minha gestação que eu sou portadora do HIV, meu filho (Ana)

A gente se culpa né ... a gente se culpa muito. A gente passa a gravidez inteira se culpando. (Maria)

Há um reposicionamento entre os participantes ao longo da sessão: a vitimização de Carlos e culpabilização dos outros.

\section{Momento 9 - outras diferenças: o futuro}

O pensar sobre a vivência com uma doença que não tem cura faz rever o passado e falar do futuro. O dialogismo faz entrecruzar o passado, o presente e o futuro. A construção da soropositividade se dá também através dos planos colocados como possíveis por aqueles que convivem com o HIV. Busca-se outros amores: soropositivos ou soronegativos? O tema dos novos relacionamentos é permeado por medos e desafios, morte e rejeição.

Marcos e Maria defendem que é possível ser aceito e amado.

Eu tenho uma amiga que foi assim (...) Eles namoravam, e ele cobrava né, porque ela usava preservativo, e ele cobrava, e ela foi ajeitando (...) Aí um dia ela criou coragem e contou e ele aceitou e eles tão junto (Marcos)

Mas, então, o meu caso foi esse (...) Porque a aceitação dele foi muito rápida (...) Eu contei, ele foi embora naquele dia, eu chorei muito. Ele foi embora e a minha tia falou: 'Ele não vai voltar mais’. No outro dia, de manhã, ele tava lá. No outro dia de manhã, eu nem tinha acordado ainda, ele já tava lá. Ele voltou. (Maria)

Ana se coloca como vítima em relação ao próprio futuro.

Então às vezes até por medo da pessoa morrer, não sei, que eles tem, então ele vai se afastar de mim. Aí eu vou sofrer muito. Porque eu aí, eu vou, eu vou sentir rejeição, preconceito. Então, aí eu acho que eu vou sofrer, não tanto pelo amor, mas pelo preconceito da pessoa. (Ana)
Neste momento nove, negociam-se no grupo as possibilidades de um novo relacionamento afetivo. Soronegativos ou soropositivos. Os primeiros podem não aceitar, os últimos podem morrer. Uns encarnam a morte social, os outros, a biológica. Marcos e Maria apontam possibilidades, seja com soropositivos ou soronegativos. Ana não consegue percebêlas. Surgem diferenças entre quem parecia igual. Carlos não fala do futuro.

\section{Momento 10: finalizando}

Neste momento o terapeuta busca fazer o fechamento da sessão. Tal como no primeiro momento, há aqui uma tarefa específica a ser realizada pelo terapeuta. Este busca ativamente circunscrever as falas dos participantes, preparandoos para o término da sessão. Neste último momento do grupo, os participantes buscam uma posição em relação ao próprio futuro. As palavras finais dos participantes são:

Viver uma vida normal? Não vai viver uma vida normal. Você tem que aceitar a viver sim, mas ela não é, fica mudada. (Mar$\cos )$

Se condenar a viver só também é duro né. (Maria)

Se eu tiver outra pessoa do meu lado eu acho que eu ia viver muito mais, muito mais, porque se diz que com amor a gente vive mais. (Ana)

Carlos permanece quieto.

O terapeuta fecha o grupo apontando a importância de refletir a respeito de como cada um, pessoalmente, tem construído suas respostas frente a AIDS.

\section{A construção da homogeneidade e do apoio no grupo}

Através da análise do eixo processual, vemos como o processo de negociação na sessão foi marcado por: a) um conjunto de trocas dialógicas baseadas em conteúdos socialmente significativos a respeito do viver com HIV/AIDS; b) por uma dinâmica de posicionamentos, um conjunto de ações realizadas pelos participantes na construção do seu lugar no grupo. Na análise desta sessão, a homogeneidade e o apoio comportaram assim, um duplo caráter: estavam referidas ao mesmo tempo, ao que se falava e ao que se fazia, aos temas e aos posicionamentos. É o jogo inseparável do falar e do fazer que operava em um processo de mútua determinação.

Enquanto tema, a homogeneidade entre os participantes se construiu a partir da semelhança dos relatos, das experiências vividas, das dúvidas e sofrimentos em um processo de apoio mútuo. Enquanto posição, a homogeneidade implicava uma determinada postura frente a si e ao outro, expressas em tais temáticas.

Pudemos observar, a partir da análise dos eixos temáticos, que nesta sessão diversos foram os temas negociados pelos participantes. Neste nível de análise a riqueza de temas, significados e sentidos explodiu. Assim foram temas da sessão: o descobrir-se soropositivo, a provável forma de infecção, a reação familiar, dos amigos e parceiros, as relações com os empregadores, com o governo, com os médicos e o sistema 
de saúde, o tratamento médico, a revelação da soropositividade, a cura, a vida com uma doença incurável, a possibilidade de uma vida com HIV. “Quem somos?” e “Onde achar apoio?” foram as questões orientadoras do movimento grupal.

Os temas foram compondo um retrato de como os participantes têm construído sua soropositividade fora do grupo. Porém, ao trazerem para discussão no grupo, fizeram de sua soropositividade o objeto de trabalho compartilhado. A discussão de determinados conteúdos implicava também a produção de certos posicionamentos frente ao grupo. Os posicionamentos consistiam em construções narrativas do self, possibilidades de si próprio, descrições de cada um negociadas ao longo da sessão: Carlos-que-sabe-de-tudo-detratamento-psicológico, Marcos-que-ficou-deprimido, Anaque-procura-outros, Maria-que-desconta-o-sofrimento. Estes posicionamentos pessoais abarcaram também uma perspectiva moral, sintetizada aqui nas posições de culpado e vítima.

O jogo de culpabilização e vitimização que ocorreu na sessão está situado no conjunto de sentidos possíveis construídos socialmente a respeito do viver com HIV/AIDS (Figueiredo \& Marcos, 1997; Parker, 1994; Sontag, 1989). Este jogo decorre de uma lógica de responsabilização associada a uma metáfora da AIDS como doença do outro e doença do mal. Não é à toa que eles se debatem nestes posicionamentos durante a sessão, nem é à toa que cabe a posição de culpado para Carlos e de vítimas para as mulheres, na primeira metade da sessão.

Assim, o lugar de cada participante na sessão decorreu das versões que cada um trazia sobre a vida com HIV/AIDS e o status desta versão, na visão dos outros participantes. Os sentidos eram dependentes de quem dizia e de quem ouvia. Neste jogo muitas posições eram negociadas. Os sentidos aí produzidos e aceitos implicariam a todos determinadas posições. Claramente, como já vimos, entre Carlos e os outros participantes houve uma divergência em muitos momentos. Negociavam-se não apenas visões sobre como comportar-se em relação ao HIV, mas versões de si mesmo. Revelar a soropositividade poderia implicar assumir-se como pessoa responsável ou como alguém merecedor de um relacionamente afetivo-sexual futuro.

A possibilidade da construção do apoio no grupo se deu a partir da construção da homogeneidade. Se não era possível experimentar o apoio através da homogeneidade expressa nos temas, esta podia ser buscada através da construção de uma homogeneidade de posições. Daí o jogo de reposicionamentos de vítima e culpado na sessão. Entre temas e posições se construiu a homogeneidade dos participantes, a possibilidade de aproximação com o outro.

Através deste estudo, foi possível analisar como a homogeneidade e o apoio, antes de serem categorias a priori, com as quais o terapeuta organiza um grupo, são efetivamente construídas na e através da situação grupal pelas pessoas aí presentes. Para além do debate de composições homogêneas/heterogêneas em relação a diversos critérios postos pelos terapeutas, é importante ressaltar o caráter construído desta homogeneidade durante o desenvolvimento da intervenção psicoterápica.

A homogeneidade é uma construção teórica existente a partir da visão do terapeuta e não uma qualidade própria aos membros do grupo. Os membros de um grupo são homogêneos em relação a algumas variáveis e heterogêneos em relação a outras. Esta homogeneidade é uma construção social, pois sendo definida a partir de uma categoria específica, se concretiza como tal quando esta categoria, a partir de determinadas condições sócio-históricas, se destaca, ganha valor e uma descrição enquanto problema que demande estratégias de enfrentamento e cuidados particulares.

Vemos assim que a possibilidade de interação entre os participantes depende, entre outros fatores, das concepções que estes trazem a respeito da categoria que os torna homogêneos. No caso desta pesquisa, concepções sobre o que seria a soropositividade mediou as interações grupais, fazendo da sessão uma situação de negociação, um exercício de construção da soropositividade, e portanto de possibilidades de vida, que nem sempre se baseou em ações de apoio ao outro, nem se deu entre pessoas que se percebiam semelhantes ou 'homogêneas'.

Apesar de conseguirem experimentar as duas posições de uma lógica da responsabilidade pela infecção pelo HIV, vítima e culpado, não conseguem superá-la. Negociam estas posições ao longo da sessão, mas permanecem nesta lógica. A vinculação deste processo grupal a um processo social mais amplo de discriminação, articulado por uma lógica do preconceito, mostra a dialogia existente entre estes diversos níveis das relações interpessoais. O grupo funciona como um microcosmo produtor de possibilidades e versões da soropositividade, sendo também determinado pelas delimitações sociais de construção da soropositividade.

\section{Considerações finais}

Metodologicamente, a análise permeada pela construção dos eixos temáticos - construção da soropositividade e construção do apoio - e, especialmente, pelo eixo processual - negociação da diferença - permitiu mostrar uma visão dialógica do processo grupal caracterizado por uma negociação de sentidos. A utilização do conceito de posicionamento possibilitou descrever o caráter dinâmico e as fortes implicações identitárias de tal negociação. O uso de delimitações temático-sequenciais permitiu apontar como uma sessão possui um fluxo de acontecimentos no tempo, cuja análise é imprescindível no processo de rastrear a construção dos sentidos em sua especificidade grupal. Estes recursos metodológicos permitiram visualizar o processo de construção dos participantes durante a sessão, trazendo para primeiro plano a produção social da homogeneidade.

Uma implicação ética desta forma de se pensar grupo diz respeito à forma de se coordenar um grupo de apoio para pessoas portadoras do HIV. Dado que a homogeneidade não está definida a priori, é importante que o grupo se construa como um espaço que, através do apoio, torne possível explorar as questões da vida com AIDS enquanto construções de 
soropositividade marcadas por determinado contexto sóciohistórico. É importante assim que o terapeuta reconheça sua ação nesta construção grupal da homogeneidade, assumindo uma postura ativa de investigar, questionar, explorar novos horizontes, mantendo um clima de negociação, para que sua intervenção questione a estabilidade das formas hegemônicas de se conversar sobre AIDS e grupo e possa contribuir na produção de mudanças, e de outras descrições e formas de se viver com o HIV/AIDS.

\section{Agradecimentos}

Nossos agradecimentos aos participantes desta pesquisa, pela colaboração; à Profa. Dra. Mary Jane P. Spink e ao Prof. Dr. Marco Antonio C. Figueiredo, pelo incentivo e sugestões no desenvolvimento da pesquisa e à FAPESP pelo apoio financeiro.

\section{Referências}

Bakhtin, M. (1997). Marxismo e filosofia da linguagem. São Paulo: Hucitec. Barros, A. S. M. (1997). Grupos de auto-ajuda. In D. E. Zimerman \& L. C. Osório (Orgs.), Como trabalhamos com grupos (pp. 107-116). Porto Alegre: Artes Médicas.

Bernstein, G., \& Klein, R. (1995). Countertransference issues in group psychotherapy with HIV-positive and AIDS patients. International Journal of Group Psychotherapy, 45, 91-100.

Bonet R., Ferrer, M. J., \& Vilajoana, J. C. (1994). Estrategias de grupo y sida: ayuda mutua. Revista de Psicologia General y Aplicada, 47, 193-200.

Catalan, J. (1995). Psychological interventions in infection with the human immunodeficiency virus. British Journal of Psychiatry, 167, 104-11.

Davies, B., \& Harré, R. (1990). Positioning: the discursive production of selves. Journal for the Theory of Social Behaviour, 20, 43-63.
Figueiredo, M. A. C., \& Marcos, M. (1997). A representação social da AIDS junto à comunidade. Jornal Brasileiro de Doenças Sexualmente Transmissíveis, 9, 8-14.

Gergen, K. J. (1994). Realities and relationships. Cambridge: Harvard University Press.

Getzel, G. S. (1991). Survival modes for people with AIDS in groups. Social Work, 36, 7-11.

Grant, D. (1988). Support groups for youth with the AIDS virus. International Journal of Group Psychotherapy, 38, 237-251.

Kelly, J. A. (1998). Group psychotherapy for persons with HIV and AIDS-related ilnesses. International Journal of Group Psychotherapy, 48, 143-162.

Kelly, J. A., Murphy, D. A., Bahr, R., Kalichman, S. C., Morgan, M. G., Stevenson, L. Y., Koob, J. J., Brasfield, T. L., \& Bernstein, B. M. (1993). Outcome of cognitive-behavioral and support group brief therapies for depressed, HIV-infected persons. American Journal of Psychiatry, 150, 1679-1686.

Lego, S. (1996). Psicoterapia de grupo com pessoas infectadas pelo HIV e seus cuidadores. In H. I. Kaplan \& B. J. Sadock (Orgs.), Compêndio de psicoterapia de grupo (pp. 390-396). Porto Alegre: Artes Médicas.

Levine S. H., Bystritsky, A., Baron, D., \& Jones, L. D. (1991). Group psychotherapy for HIV-seropositive patients with major depression. American Journal of Psychotherapy, 45, 413-424.

Parker, R. (1994). A construção da solidariedade. Rio de Janeiro: Relume Dumará, ABIA, IMS-UERJ.

Rasera, E. F., \& Japur, M. (2001). Contribuições do pensamento construcionista para o estudo da prática grupal. Psicologia: Reflexão e Crítica, 14(1), 201-209.

Siebert, M. J., \& Dorfman, W. L. (1995). Group composition and its impact on effective group treatment of HIV and AIDS patients. Journal of Developmental and Physical Disabilities, 7(4), 317-334.

Sontag, S. (1989). AIDS e suas metáforas. São Paulo: Companhia das Letras.

Spink, M. J. P. (1999). Práticas discursivas e produção de sentidos no cotidiano. São Paulo: Cortez.

Spector, I. C., \& Conklin, R. (1987). AIDS group psychotherapy. International Journal of Group Psychotherapy, 37, 433-439.

Tunnell, G. (1991). Complications in group psychotherapy with AIDS patients. International Journal of Group Psychotherapy, 41, 481-498.

Emerson F. Rasera é doutorando em Psicologia da Faculdade de Filosofia Ciências e Letras da Universidade de São Paulo - Ribeirão Preto.

Marisa Japur é doutora do Departamento de Psicologia e Educação da Faculdade de Filosofia Ciências e Letras da Universidade de São Paulo - Ribeirão Preto.

Endereço para correspondência: Departamento de Psicologia e Educação, Faculdade de Filosofia, Ciências e Letras de Ribeirão Preto, Universidade de São Paulo. Avenida dos Bandeirantes, 3900 - CEP 14090-910 Ribeirão Preto - São Paulo - Tel.: (16) 602-3735 - Fax: (16) 602-3793 - E-mail: mjapur@ffclrp.usp.br 